\title{
LITIGIOUSNESS IN AUSTRALIA: LESSONS FROM COMPARATIVE LAW
}

\section{LEON WOLFF *}

\begin{abstract}
How litigious are Australians? Although quantitative studies have comprehensively debunked the fear of an Australian civil justice system in crisis, the literature has yet to address the qualitative public policy question of whether Australians are under- or over-using the legal system to resolve their disputes. On one view, expressed by the insurance industry, the mass media and prominent members of the judiciary, Australia is moving towards an American-style hyper-litigiousness. By contrast, Australian popular culture paints the typical Australian as culturally averse to formal rights assertion. This article explores the comparative law literature on litigiousness in two jurisdictions that have attracted significant scholarly attention - the United States and Japan. More specifically, it seeks to draw lessons from this literature for both understanding litigiousness in modern Australia and framing future research projects on the issue.
\end{abstract}

To be, or not to be, that is the question:

Whether 'tis Nobler in the mind to suffer

The Slings and Arrows of outrageous Fortune,

Or to take Arms against a Sea of troubles

And by opposing end them ...

The Tragedy of Hamlet, Prince of Denmark,

First Folio 1623, III.i.56-60

William Shakespeare

\section{INTRODUCTION}

Imagine a modern-day Hamlet. Instead of contemplating whether 'to be or not to be' in his grief over the death of his father, King Hamlet, suppose he was deliberating legal action against his father's killers for the intentional infliction of emotional distress. 'To sue, or not to sue', Hamlet might muse, 'that is the question. Is it nobler to suffer the slings and arrows of life's injustices, or take arms - backed by a team of well-paid and highly educated lawyers - in a court of law and by litigating end them?'

\footnotetext{
* Associate Professor, Faculty of Law, Bond University; Co-director, Australian Network for Japanese Law; and Deputy Director, Centre for Law, Governance and Public Policy.
} 
To be sure, this is hardly the inspired poetry of Shakespeare's original play. Nor is it a theme as confounding and as universal as struggling over the meaning of life, the theme devised by Shakespeare for his original hero. Still, $21^{\text {st }}$ century Hamlet does articulate a modern-day concern: is resort to law the best answer to our woes? Shakespeare, of course, already had his own answer. In his play Henry VI, Part II, one of his characters says: 'The first thing we do, let's kill all the lawyers'. ${ }^{1}$ Clearly, Shakespeare was questioning the social utility of lawyers and litigation. Four hundred years later, there are even more lawyers, more judges, more statutes, more cases - indeed, more law. Is it, as Shakespeare himself might have concluded, too much?

Comparative law provides mixed answers to modern-day Hamlet's dilemma. Modern democracies need a robust civil justice system to hear and resolve legal disputes. After all, the rule of law - much like democracy and the separation of powers - is a cherished value in most systems of government around the globe. But overuse or underuse of the legal system may indicate a social problem. This is where the debate on litigation takes different twists and turns depending on the jurisdiction under the spotlight. Two jurisdictions, the United States and Japan, have occupied a significant corpus of comparative law analysis on the issue of litigiousness, albeit for different reasons. In the United States, the concern is whether Americans sue too readily. ${ }^{2}$ In Japan, it is that Japanese people are too reluctant to invoke the law to protect their rights. ${ }^{3}$

But what about Australia? Are Australians too litigious? Or, at least, is Australian society on the fast-track to becoming too litigious? These are questions that have attracted some — but not enduring — research and debate. Certainly, interest was at its highest at the turn of the $21^{\text {st }}$ century, when the Australian states were contemplating statutory reforms to tort law. This reform effort was in response to a perceived crisis in the insurance industry precipitated by a supposed spike in negligence claims and compensation awards. Newspapers reported an 'explosion of negligence cases before Australian courts'. ${ }^{4}$ Politicians complained of 'excessive litigation'

\footnotetext{
${ }^{1}$ William Shakespeare, Henry VI, Part II, IV.ii.72.

2 Eric Feldman, The Ritual of Rights in Japan: Law, Society, and Health Policy (Cambridge University Press, 2000) 1-15.

${ }^{3}$ Ibid. See also John O Haley, 'Litigation in Japan: A New Look at Old Problems' (2002) 10 Willamette Journal of International Law and Dispute Resolution 121, 122.

${ }^{4}$ David Nason, 'Crisis Can Be Traced to a Snail', Weekend Australian (Sydney), 30-1 March 2002, quoted in Sharyn Roach Anleu and Wilfred Prest, 'Litigation: Historical and Contemporary Dimensions' in Sharyn Roach Anleu and Wilfred Prest (eds), Litigation: Past and Present (UNSW Press, 2004) 2, 10. See also Richard Refshauge, 'Our Litigious Society and Its Effect on the Public Sector' (2002) 105 Canberra Bulletin of Public Administration 1.
} 
caused by the 'current adversarial litigious legal framework' ${ }^{5}$ Judges — both judicially ${ }^{6}$ and extra-judicially ${ }^{7}$ — complained of crippling case workloads due to burgeoning litigation. Scholars ${ }^{8}$ questioned whether Australia was entering an era of American-style 'lawsuit terrorism'. ${ }^{9}$ The Australian Law Reform Commission ('ALRC') investigated whether Australia's court system was in crisis. ${ }^{10}$ However, since the Australian states enacted civil liability statutes, ${ }^{11}$ the question of litigiousness in Australia has largely withered as an area of scholarly ${ }^{12}$ or policy ${ }^{13}$ concern.

${ }^{5}$ Ted Wright and Angela Melville, 'Hey, But Who's Counting? The Metrics and Politics of
Trends in Civil Litigation' in Sharyn Roach Anleu and Wilfred Prest (eds), Litigation: Past and Present (UNSW Press, 2004) 96, 96-7.

${ }^{6}$ Melchior v Cattanach [2001] QCA 246, [60] (McMurdo P); Lisle v Brice [2002] 2 Qd R 168, 174 (Thomas JA); Swain v Waverley Municipal Council (2005) 213 ALR 249, 251 (Gleeson CJ); Re Jan Blaszczyk and Secretary, Department of Family and Community Services [2005] ATA 1224, [23] (Savage-Davis and Tovey, members); Lade \& Co Pty Ltd v Black [2006] 2 Qd R 531, 543 (Keane JA).

${ }^{7}$ Kenneth Hayne, 'Restricting Litigiousness' (2004) 78 Australian Law Journal 381; David Ipp, 'Taking Responsibility' (2004) 48(9) Quadrant $16<$ http://search.informit.com.au/ documentSummary;dn=217740197547211;res=IELLCC>; D A Ipp, 'Reforms to the Adversarial Process in Civil Litigation - Part I' (1995) 69 Australian Law Journal 705; James Spigelman, 'Negligence and Insurance Premiums: Recent Changes in Australian Law', The Spencer Mason Trust Lecture (Auckland, 27 May 2003).

${ }^{8}$ Anleu and Prest, above n 4; Peter Cane, 'Reforming Tort Law in Australia: A Personal Perspective' (2003) 27 Melbourne University Law Review 649; Caspar Conde, 'The Foresight Saga: Risk, Litigiousness and Negligence Law Reforms' (2004) 20(3) Policy 28; Rob Davis, 'Exploring the Litigation Explosion Myth' (2002) 49 Plaintiff 4; Rob Davis, 'The Tort Law Crisis' (2002) 25(3) University of New South Wales Law Journal 865; Refshauge, above n 4; Wright and Melville, above $n 5$.

${ }^{9}$ Dennis Prager, 'Here's an Idea, Let’s Bean All the Lawyers', LA Times (Los Angeles), 9 August 2001, B15.

${ }^{10}$ ALRC, Reforming Justice: A Review of the Federal Justice System, Report No 89 (2000). See further David Weisbrot, 'Reform of the Civil Justice System and Economic Growth: Australian Experience' (2003) 6 Flinders Journal of Law Reform 235; David Weisbrot and Ian Davis, 'Litigation and the Federal Civil Justice System' in Sharyn Roach Anleu and Wilfred Prest (eds), Litigation: Past and Present (UNSW Press, 2004) 122.

${ }^{11}$ See, eg, Civil Liability Act 2003 (Qld).

${ }^{12}$ For more recent scholarship addressing litigation and litigiousness in Australia, see Kylie Burns, 'Distorting the Law: Politics, Media and the Litigation Crisis: An Australian Perspective' (2007) 15 Torts Law Journal 195; Bobette Wolski, 'Reform of the Civil Justice System Two Decades Past - Implications for the Legal Profession and for Law Teachers' (2009) 21(3) Bond Law Review 192; Bobette Wolski 'Reform of the Civil Justice System 25 Years Past: (In)adequate Responses from Law Schools and Professional Associations? (and How Best to Change the Behaviour of Lawyers)' (2011) 40 Common Law World Review 40.

${ }^{13}$ For a recent policy speech addressing litigation levels in Australia, see Nicola Roxon, 'Speech to the New South Wales Bar Association Alternative Dispute Resolution Workshop' (4 August 2012) <http://www.lawchat.com.au/wp-content/uploads/2012/08/Roxon-disputeresolution-speech-NSW-Bar.pdf $>$. 
This article seeks to re-open the debate about Australian litigiousness. The rationale for doing so is that the current literature provides only partial and incomplete answers to the question 'Are Australians too litigious?' For example, the literature makes it clear that claims of an Australian embracing of American-style excessive legalism are based on unreliable data and selective anecdotes. ${ }^{14}$ Quantitative studies ${ }^{15}$ amply demonstrate that Australia's system of civil justice is not in crisis; indeed, litigation rates have been consistently falling since the turn of the $21^{\text {st }}$ century. ${ }^{16}$ But litigiousness — or the 'fondness' ${ }^{17}$ for law — is a cultural question: it concerns a society's appetite for law; its preparedness to invoke formal law to articulate claims, defend rights and resolve disputes. As such, it is a qualitative, not a quantitative, issue.

The article turns to the comparative law literature for lessons on the possibilities and pitfalls involved in the making of such qualitative claims about litigation and litigiousness. In particular, it highlights the contrasting cases of the United States and Japan. The article argues that, since litigiousness is difficult to measure directly, cultural stereotypes persist in much popular and academic literature - the stereotypes of a rights-obsessed, litigation-loving America and a socially harmonious, litigation-averse Japan. Comparative law scholars, however, strongly contest — and, often, outright reject — these populist impressions.

These comparative law findings have implications for understanding litigiousness in Australia. Two contrasting images currently compete to define Australian identity. The first is that Australians are laid-back, friendly and easy-going, an image projected in such Australian vernacular expressions as a 'fair go', 'she'll be right, mate' and 'no worries'. The second, popularised in the mass media, is that Australians are becoming too 'American' in their approach to rights and litigation. ${ }^{18}$ On this second view, the Australian legal system is heading for crisis. More than that, Americanisation may spell the decline of society, as citizens prioritise their individual rights over their collective responsibilities. ${ }^{19}$ This article explores how commentators seek to correlate these conflicting impressions about Australian identity with Australian litigiousness. It concludes by suggesting that the better view might lie somewhere between these extremes.

\footnotetext{
${ }^{14}$ Wright and Melville, above n 5, 100, 111, 113.

${ }^{15}$ ALRC, above n 10; Wright and Melville, above n 5.

${ }^{16}$ Productivity Commission, Report on Government Services 2011 (2011) Table 7A.4.

${ }^{17}$ Hayne, above n 7, 381.

${ }^{18}$ Davis, 'The Tort Law Crisis', above n 8, 865-6.

${ }^{19}$ Refshauge, above n 4, 4; cf Mary Ann Glendon, Rights Talk: The Impoverishment of Political Discourse (The Free Press, 1991) 9, 16, 107.
} 
The first part of this article introduces the contesting definitions of litigiousness and the contrasting views on its social and economic utility. The second part explores the cultural assumptions typically made about strong legal consciousness in the United States and weak legal consciousness in Japan. It also surveys some of the critical scholarly reactions to these assumptions. Finally, the article applies these ideas to the Australian case, concluding that Australians are neither unduly diffident nor overly enthusiastic about invoking the law to resolve their disputes.

\section{LITIGATION: GOOD OR EVIL?}

Let us return to modern-day Hamlet's dilemma. The question he posed for himself — one that many modern citizens similarly pose for themselves when confronted with conflict or injustice - raises a set of complex questions about the social value of litigation. Is litigation a good because it promotes individual rights and a healthy liberal democracy? ${ }^{20}$ Or is it a disease crippling civil society by privileging selfishness over community? ${ }^{21}$ Does litigation provide just compensation for those who are wronged? Or does it precipitate spikes in insurance premiums that threaten professional services and public events? ${ }^{22}$

This is the nub of the litigiousness debate. And it is a contentious one. Indeed, it is so highly charged that there is not even agreement over what litigiousness means. For Feldman, for example, litigiousness is the willingness to assert legal rights. ${ }^{23}$ For Hayne, a Justice of the High Court of Australia, litigiousness 'suggests an eagerness to go to law or even a fondness for the process'. ${ }^{24}$ For Haley, litigiousness is the gauge by which we measure the efficacy of law in directing social behaviour. ${ }^{25}$ Each definition has its own point of emphasis. In the first, litigiousness is about rights assertion; in the second, it is about over-use or abuse of the legal process; in the third (and the widest), it is about law's relevance to social order. A compromise position might be to define litigiousness as the extent to which people are both conscious of the law and prepared to engage in formal legal processes. Litigious people are those who frame their disputes in legal, adversarial terms; non-litigious people are those who prefer to resolve their complaints through

\footnotetext{
${ }^{20}$ Stewart Scheingold, The Politics of Rights: Lawyers, Public Policy, and Political Change (Yale University Press, $2^{\text {nd }}$ ed, 2004) xvii.

${ }^{21}$ Leon Kass, 'Is There a Right to Die?' (1993) 23(1) Hastings Centre Report 34, 34.

${ }^{22}$ Spigelman, above n 7, cited in Conde, above n 8, 29.

${ }^{23}$ Feldman, above $\mathrm{n} 2,1$.

${ }^{24}$ Hayne, above n $7,381$.

${ }^{25}$ Haley, above n 3, 122.
} 
informal means, such as negotiations or discussions, because they prefer to preserve relationships rather than rupture them.

At first blush, this difference over definition might reflect different value judgments about the social value of litigation. Thus, Haley and Feldman see it as a good; Hayne, as an evil. In fact, it is more complex than that. Hayley and Feldman, as comparative lawyers, are attempting to explain low levels of litigation in Japan, especially by American standards. They seek to defend Japan against the charge that its legal system is failing its people. By contrast, Hayne, as a serving Australian judge, sees litigation every day of his professional life and presumably is concerned that it does not spin out of control. There is a strong imperative for him to do so because, as a judge, he sees first-hand the costs of litigation (both financial and emotional) and believes that its over-use outweighs its benefits to democracy, freedom and social justice. ${ }^{26}$ He is not the only judicial officer to think so. ${ }^{27}$

Litigiousness is also a barometer of a nation's economic health. According to the prevailing orthodoxy, law, lawyers and litigation are both essential to, and a burden on, the economy. Too little rights-assertion points to a weakness in the legal infrastructure that is necessary to support a market economy. Lawand-development theorists have long posited that a strong legal system is essential if a stable and predictable environment for investment and a transparent and efficient system for enforcing property rights and investment decisions is to be delivered. ${ }^{28}$ Too much law, however, is a drag on economic growth. Indeed, empirical studies have shown an inverse relationship between the number of lawyers and the vibrancy of the economy. The explanation for this is that lawyers, unlike entrepreneurs and engineers, do not generate wealth; they are rent-seekers who add complexity and other costs to the transaction of business. ${ }^{29}$

\footnotetext{
${ }^{26}$ Hayne, above n 7, 382.

${ }^{27}$ See cases referred to above $n 6$.

${ }^{28}$ For a summary of the theoretical literature linking law and economic development, see Kanishka Jayasuriya, 'Introduction: A Framework for Analysis of Legal Institutions in East Asia' in Kanishka Jayasuriya (ed), Law, Capitalism and Power in East Asia: The Rule of Law and Legal Institutions (Routledge, 1999) 1, 3-7.

${ }^{29}$ Derek C Bok, 'A Flawed System of Law Practice and Training' (1983) 33 Journal of Legal Education 570, 572-4, cited in Curtis Milhaupt and Mark West, 'Law's Dominion and the Market for Legal Elites in Japan’ (2003) 23(2) Law and Policy in International Business 451, 452.
} 


\section{Comparative Litigiousness and Popular Culture}

The challenge for any liberal society, then, is to keep litigation levels in a state of balance: too much undermines social cohesion and economic activity; too little threatens social justice and economic stability. But where or how to strike this optimum balance is extremely complex. This is largely because litigiousness is difficult to measure and compare directly. ${ }^{30}$ For one, it is an open question whether litigiousness is indicated by simply filing legal proceedings, proceeding to trial, or concluding a dispute with a judicially determined outcome. ${ }^{31}$ For another,

variations in institutional conditions, including court and professional structures, procedural and substantive rules, as well as recording practices, make it extremely difficult to compare litigation rates across national boundaries in a valid and meaningful fashion. ${ }^{32}$

Given the complications associated with collecting, validating and comparing quantitative data, it is not surprising that much comparative commentary on litigiousness resorts to cultural portrayals. Take the United States, for example. For Australians, it is tempting to derive clues about American litigiousness from American popular culture. ${ }^{33}$ After all, American sitcoms and dramas appear nightly on Australian television screens; Hollywood movies dominate theatrical releases; and American pop, rock, hip-hop and rap feature heavily on Australian music charts. A survey of American popular culture quickly reveals that law and rights-assertion are dominant plot points and themes. From To Kill a Mockingbird (1962) to The Lincoln Lawyer (2011), American movies depict lawyers as heroes. From LA Law (19861992) to The Good Wife (2010-), American television uses the court-room to debate contemporary social and political issues. And from Bob Dylan's Blowin' in the Wind (1963) to Christina Aguilera's Beautiful (2003), American popular music lyrics frequently champion civil rights. Indeed, many scholars do argue that American popular culture reveals central truths about American legal culture. ${ }^{34}$ And the message is that Americans are over-reliant on law. As Davis argues, 'the meme [is] that the legal system has gone mad. That 'Santa Claus' judges have encouraged a culture in which everyone feels there is no injury without blame, and no blame without a claim. ${ }^{35}$ Others

\footnotetext{
${ }^{30}$ Anleu and Prest, above n 4, 6-8.

${ }^{31}$ Ibid 6.

32 Ibid 8.

${ }^{33}$ See, eg, Kathy Laster with Krista Breckweg and John King, The Drama of the Courtroom (Federation Press, 2000).

${ }^{34}$ Lawrence M Friedman, 'Law, Lawyers, and Popular Culture' (1989) 98(8) Yale Law Review 1579.

${ }^{35}$ Davis, 'The Tort Law Crisis', above n 8, 866.
} 
agree: the incidence of law-suits is 'exploding'. ${ }^{36}$ Litigation is a form of warfare $^{37}$ and Americans are 'gorged' 38 on legal rights:

American rights talk is set apart by the way that rights, in our standard formulation, tend to be presented as absolute, individual, and independent of any necessary relation to responsibilities ... [W]e have observed a tendency to formulate important issues in terms of rights; a bent for stating rights claims in a stark, simple, and absolute fashion; an image of the rightsbearer as radically free, self-determining, and self-sufficient; and the absence of well-developed responsibility talk ... and a consequent carelessness regarding the environments that human beings and societies require in order to flourish. ${ }^{39}$

Other scholars are less sure. Ramseyer and Rasmusen, for example, admit that litigation in the United States is more voluminous than in other advanced economies — but not by much. ${ }^{40}$ The ratio of law suits between the United States and the United Kingdom, for example, is less than the ratio between the United Kingdom and Canada. The Americans have fewer judges than the French. And although there are more lawyers per capita in the United States than anywhere else in the world, Australia is not very far behind. ${ }^{41}$ Other analysts go further and argue that American popular culture misrepresents real American legal culture. According to their empirical studies, Americans invoke the law only rarely, most preferring to resolve their disputes using non-legal means. ${ }^{42}$

\footnotetext{
${ }^{36}$ Walter K Olsen, The Litigation Explosion: What Happened when America Unleashed the Lawsuit (Truman Talley Books, 1995).

${ }^{37}$ Prager, above $n 9$.

${ }^{38}$ Feldman, above n 2, 2.

${ }^{39}$ Glendon, above n 19, 9, 107.

${ }^{40}$ J Mark Ramseyer and Eric B Rasmusen, ‘Are Americans More Litigious? Some Quantitative Evidence' in F H Buckley (ed), The American Illness: Essays on the Rule of Law (Yale University Press, 2011) 1, 27.

${ }^{41}$ Ibid.

${ }^{42}$ See, eg, Marc Galanter, 'Reading the Landscape of Disputes: What We Know and Don't Know (and Think We Know) about our Allegedly Contentious and Litigious Society' (1983) 31 University of California Law Review 4; Carol J Greenhouse, Praying for Justice: Faith, Order, and Community in an American Town (Cornell University Press, 1986); Laura Nader, 'A Litigious People' (1988) 22(5) Law and Society Review 1017; Robert C Ellickson, Order without Law; How Neighbours Settle Disputes (Harvard University Press, 1991); M P Baumgartner, 'On the Overlegalized Conception of Modern Society' (1993) 22(3) Contemporary Sociology 336; Carol J Greenhouse, Barbara Yngvesson and David M Engel, Law and Community in Three American Towns (Cornell University Press, 1994); Robert L Nelson, 'Ideology, Scholarship, and Sociolegal Change: Lessons from Galanter and the "Litigation Crisis”' (1998) 21(5) Law and Society Review 677.
} 
Japan, by contrast, is said to be a non-litigious society. Currently, 30516 lawyers serve a population of 127 million people - about 1 for every 4000 citizens. ${ }^{43}$ Nearly 30 per cent of Japan's court districts have one lawyer (or none) practising in the region. Large commercial law firms are uncommon. ${ }^{44}$

With so few lawyers, litigation rates are very low. In the mid-1990s, for example, there were only 9.3 cases per 1000 people in Japan compared to 123.2 cases in Germany, 74.5 in the United States, 64.4 in the United Kingdom, and 40.3 in France. ${ }^{45}$ Even by Asian standards, this rate is low. Based on statistics for new civil cases filed for trial in district courts in Japan, South Korea, and Taiwan in 1995-1996, South Korea had five times as many filings and Taiwan about twice as many. ${ }^{46}$ Some commentators claim that litigation rates are steadily increasing in Japan, especially since the beginning of the $21^{\text {st }}$ century. ${ }^{47}$ However, others explain that most of the increase is attributable to the surge in expedited debt recovery cases following the bursting of the economic bubble. They note that ordinary contested cases - a better barometer of litigiousness — still remain at relatively low levels. ${ }^{48}$

Why is the rate of litigation so much lower in Japan compared to other modern democratic economies? One of the more popular explanations is the cultural theory of Japanese civil justice. Low levels of litigation are attributed to Japanese national traits of harmony and groupism. ${ }^{49}$ As far back as the 1960s, Japanese socio-legal scholar Takeyoshi Kawashima argued that this pre-modern cultural emphasis on community harmony over individual interests accounted for the low demand for legal professional services. As Japan moves inexorably to embrace a Western-style modernity, Kawashima predicted, more Japanese would eventually accept litigation as a means to

\footnotetext{
43 'Too Many Lawyers in Japan, Says Ministry of Internal Affairs', Majirox News (online), 23 April $2012<$ http://www.majiroxnews.com/2012/04/23/too-many-lawyers-in-japan-saysministry-of-internal-affairs/>.

${ }^{44}$ Bruce Aronson, ‘The Brave New World of Lawyers in Japan’ (2007) 21 Columbia Journal of Asian Law 45, 49.

45 Iwao Sato, 'Judicial Reform in Japan in the 1990s: Increase of the Legal Profession, Reinforcement of Judicial Functions and Expansion of the Rule of Law (2002) 5(1) Social Science Japan Journal 71, 71.

${ }^{46}$ Haley, above $n$ 3, 124.

${ }^{47}$ Tom Ginsburg and Glenn Hoetker, 'The Unreluctant Litigant? An Empirical Analysis of Japan’s Turn to Litigation’ (2006) 35(1) Journal of Legal Studies 31.

${ }^{48}$ Takao Tanase (trans Luke Nottage and Leon Wolff), Community and the Law: A Critical Reassessment of American Liberalism and Japanese Modernity (Edward Elgar, 2010) 158.

${ }^{49}$ Kenneth L Port, 'The Case for Teaching Japanese Law at American Law Schools' (1994) 43 De Paul Law Review 643, 659-70.
} 
resolve their disputes. ${ }^{50}$ Several scholars have endorsed Kawashima's thesis, although with different normative conclusions. For example, Chin and Lawson $^{51}$ agree that the Japanese are culturally averse to law. Japanese attitudes to law have been shaped by geographic isolation, ethnic homogeneity and religious thought. Instead of law, the authors submit, nonlegal forces ensure social order. Like Kawashima, the authors suggest that only social change will bring about a change of legal consciousness; but whether or not change occurs, they evaluate Japanese attitudes to law quite positively as 'law of the subtle mind'. By contrast, Inoue assesses Japanese legal culture more negatively. The communitarian ethic — which carries with it an aversion to the individualism of rights-talk — is a threat to liberalism, Inoue warns. $^{52}$

Comparative law researchers have strongly criticised the cultural explanation for litigation levels in Japan and have offered alternative explanations. One prominent theory stresses institutional factors over cultural attributes. Specifically, this theory points to a number of institutional disincentives to litigation within the legal system. ${ }^{53}$ For example, Hayley, while acknowledging that Japanese file relatively fewer civil suits compared to citizens in other industrialised countries, points to evidence that the Japanese are not reticent about asserting their legal rights. Rather, according to Hayley, institutional incapacity - few lawyers and judges, ${ }^{54}$ the discontinuous nature of trials, and an inadequate range of remedies and enforcement powers ${ }^{55}$ establishes a barrier to bringing suit in Japan. Other institutional barriers include a lack of pre-trial discovery procedures, high contingency fees, prohibitive court costs and the absence of a jury system. ${ }^{56}$

\footnotetext{
${ }^{50}$ Takeyoshi Kawashima, 'Dispute Resolution in Contemporary Japan’ in Arthur von Mehren (ed), Law in Japan: The Legal Order in a Changing Society (Harvard University Press, 1963) 41.

${ }^{51}$ Chin Kim and Craig M Lawson, 'The Law of the Subtle Mind: The Traditional Japanese Conception of Law' (1979) 28 International and Comparative Law Quarterly 461.

${ }^{52}$ Tatsuo Inoue, 'The Poverty of Rights-Blind Communality: Looking through the Window of Japan’ (1993) Brigham Young University Law Review 517.

${ }^{53}$ Port, above n 49, 659-70.

${ }^{54}$ John O Haley, 'The Myth of the Reluctant Litigant' (1978) 4(2) Journal of Japanese Studies 359, 380.

${ }^{55}$ Ibid 387.

${ }^{56}$ Nobutoshi Yamanouchi and Samuel J Cohen, 'Understanding the Incidence of Litigation in Japan: A Structural Analysis' (1991) 25(2) The International Lawyer 443. Japan introduced a quasi-jury system in 2009; however, this is more accurately described as a 'lay judge' system where citizens join professional judges in deciding questions of fact and law and is, at any rate, restricted to serious criminal matters: see Douglas G Levin, 'Saiban-in Seido: Lost in Translation? How the Source of Power Underlying Japan's Proposed Lay Assessor System May Determine its Fate' (2011) 10(1) Asia-Pacific Law and Policy Journal 199.
} 
Yet another counter-explanation is that the Japanese civil justice system is politically manipulated. According to this view, political elites - notably, the bureaucracy - manage the pace and direction of social change by channelling disputes away from the courts and into the hands of governmentannexed informal dispute resolution facilities. Adherents of this view submit that lower levels of litigation in Japan have nothing to do with a cultural aversion to law; they are more the result of deliberate conservative government policy. ${ }^{57}$ Japanese political conservatives prefer informal resolution of disputes because, it is submitted, they view litigation as a threat to the political and social status quo and, therefore, take calculated steps to discourage litigation. ${ }^{58}$

A more controversial explanation for low litigation rates in Japan is advanced by law and economics scholars who explain rates of litigation in terms of behaviourist economics. On this view, Japanese prefer to settle because damages are predictable and settlement is the cheaper option. It is more economically 'rational' (or cost effective) — to bargain in the shadow of the law rather than pursue litigation. Law and economics scholars argue that a Japanese cultural aversion to law is pure myth. ${ }^{59}$ Ramseyer and Nakazato, for example, contend that the Japanese preference to settle cases out of court is not culturally pre-determined nor compelled by structural impediments in the legal system. ${ }^{60}$ Japanese settle because they can predict what damages they might get if they pursued their dispute in court and, therefore, simply bargain 'in the shadow of the law'. Settling is cheaper and quicker than prosecuting a case to trial. This shows that the Japanese are bound by rationality, not culture, because they maximise - rather than forsake - their self-interest. And it suggests that the Japanese legal system works, because, if disputants are settling their disputes in light of expected litigated outcomes, then clearly law is structuring behaviour. ${ }^{61}$ Consider, for example, noise pollution from karaoke machines, a big problem in congested Japan. ${ }^{62}$ According to case law databases, only about 40 disputes have ever been brought before the Japanese courts. By contrast, nearly 100000 cases are heard each year by pollution complaint counsellors who offer an informal dispute resolution service

\footnotetext{
${ }^{57}$ Port, above n 49, 670.

${ }^{58}$ Frank K Upham, Law and Social Change in Postwar Japan (Harvard University Press, 1987) 16-27, 124-65.

${ }^{59}$ Port, above n 49, 661-2, 668-9.

60 J Mark Ramseyer and Minoru Nakazato, 'The Rational Litigant: Settlement Amounts and Verdict Rates in Japan’ (1989) 18 Journal of Legal Studies 263.

61 Ibid.

${ }^{62}$ Mark West, Law in Everyday Japan: Sex, Sumo, Suicide, and Statutes (University of Chicago Press, 2005) 90-1. See also Mark West, 'The Pricing of Shareholder Derivative Actions in Japan and the United States’ (1994) 88 Northwestern University Law Review 1436.
} 
established by the dispute law. Under the law, counsellors have strong, judgelike powers to consult with residents, investigate pollution incidents, and provide guidance and advice. Filing a complaint involves no direct monetary cost, does not preclude filing a concurrent (or subsequent) law suit, and allows complaints to be heard and dealt with relatively swiftly due to the lack of formalities.

\section{Litigiousness and Australian Popular CULture}

Culture might also allure as an explanation of Australian attitudes to law. Consider the two quintessentially Australian expressions 'she'll be right, mate' and 'no worries'. It matters little whether most people actually use these expressions or revert to American vernacular such as 'cool' or 'awesome' instead. What does matter is that the expressions project images of who we are or, more accurately, who we think we are as Australians: laid-back, informal and easy-going with an anti-authoritarian streak and jocular contempt for elites. Like most cultural assumptions, however, this self-image is open to critical scrutiny. For example, Australians are not as laid-back as they might like to think. Indeed, studies show that Australians work some of the longest hours of any workers in the industrialised world. ${ }^{63}$ Furthermore, the easy-going nature of Australians does not necessarily extend to welcoming outsiders. Immigration policy, for example, has long been a sore point in Australian external relations, dating back to the post-WW2 White Australia Policy ${ }^{64}$ and extending to today's political preference for off-shore processing of asylum-seekers. Despite these apparent contradictions, this self-image is central to the Australian identity. Certainly, it saturates our popular culture. Prime-time television shows, for example, celebrate low-key family life in middle-class suburbia. Neighbours and Home and Away, two of the longest running soaps on Australian television, illustrate this perfectly. The construction of this self-image through popular culture is to be contrasted with: American soap operas which focus on the life of the extravagantly wealthy (Young and the Restless, Days of Our Lives, Dallas and, more recently, Revenge); British serials that portray the battles of working-class existence (Eastenders and Coronation Street); and Japanese television series that prioritise the value of work by situating the drama within generic office settings with white collar protagonists (such as Tokyo Love Story).

${ }^{63}$ Clive Hamilton, 'Overconsumption in Australia: The Rise of the Middle-Class Battler' (Discussion Paper No 49, The Australia Institute, 2002) 15-16.

${ }^{64} \mathrm{~J}$ V D'Cruz and William Steele, Australia's Ambivalence towards Asia (Monash University Press, 2003) 7-9. 
What insights does this offer for litigation behaviour in Australia? A cultural analysis would tend to suggest that Australians are - or, at least, should be - ambivalent about the law. With the Australian cultural predisposition to informality, mateship and the 'fair go', most Australians would be expected to prefer to resolve their conflicts informally rather than through legal means; to preserve their personal and professional relationships rather than place them at risk through financially and emotionally draining litigation; and settle their disputes using an innate sense of justice rather than abstract legal rules.

Popular culture reinforces this expectation. In contrast to the position in the United States, Australian television and film make infrequent use of lawyers as characters and court-room battles as dramatic plot points. ${ }^{65}$ Where they do, the legal process is either mocked for being un-Australian or criticised for destroying personal relationships and lives. In The Castle (1997), for example, an ordinary family sues a developer to prevent the developer resuming its land to extend the Melbourne Airport. The movie pokes fun at the law, highlighting how alien court-room procedures and legal language are to the film's hero, a well-meaning, likeable and community spirited Aussie battler. In the ABC series Sea Change (1998-2000), a corporate lawyer in a large, urban law firm quits her job and finds personal happiness in a coastal community, serving as the local magistrate. A parade of quirky characters appear in her courtroom, whose complaints, she finds, are usually better resolved through informal, community-affirming strategies than formal fines or custodial sentences. More recently, the ABC eight-part mini-series The Slap (2011) comprised a minor story line in which a young mother brings formal charges against her friend's husband for slapping her young son at a family barbeque. The lead-up to her court case places pressure on her marriage and strains her relationships with her friends, and the court case ends in disaster when she is humiliated on the witness stand. Australian popular culture, in short, largely neglects law as worthy of narrative attention and, when it does, treats it with comical or derisive scorn. The thesis is clear: formal law is not a good cultural fit with the Australian identity.

The alternative view is that litigiousness, far from being alien to Australian cultural values, is actually spinning out of control. If this is occurring, it might be attributable to the cultural 'Americanisation' of Australian society. ${ }^{66}$ Australians, some suggest, are becoming more willing to assert their rights;

\footnotetext{
${ }^{65}$ More common is the drama or comedy about family and friends in ordinary suburban or community life, or workplace dramas set in hospitals, police stations or emergency services: consider the movies Red Dog (2011) and Muriel's Wedding (1994) and the television series Packed to the Rafters (2008-), Offspring (2010-), Sea Patrol (2007-2011), All Saints (19982009) and The Secret Life of Us (2001-2005).

${ }^{66}$ Davis, 'The Tort Law Crisis', above n 8, 866.
} 
indeed, 'the exercise and assertion of rights is legitimated and increasingly encouraged'. ${ }^{67}$ They are more prepared to complain; the rise in watchdogs and complaints-handling bodies such as the Human Rights and Equal Opportunity Commission, the Insurance Ombudsman and the Banking Ombudsman, facilitates this option. ${ }^{68}$ And Australians are more inclined to resort to litigation to effect social and economic change instead of relying on political action or advocacy. ${ }^{69}$ In particular, they increasingly look to the courts for financial support when struck by misfortune:

All too often the courts are asked to act as an avenue to welfare rather than compensation. Guy Swain was left a quadriplegic after diving into a sandbank at Bondi beach ... Kerry Melchior sought and was awarded the costs of raising her (perfectly healthy) son Jordan, who was born after a botched sterilisation procedure. Diane Burns sued Hoyts after she was injured trying to sit in a cinema seat that had folded back. And Rosalie Cole, who had a blood alcohol content of $0.238 \mathrm{gm}$ per $100 \mathrm{ml}$ when she was run over by a four wheel drive, sought compensation from the South Tweed Heads Rugby Football Club for her injuries. All this serves to create ... [a] risk-averse society. ${ }^{70}$

Three key social institutions paint litigiousness as a problem in Australia. The first is the mass media. As Refshauge notes, television news and newspaper reports are awash with stories about litigation and legal risk: from cases of disabled children suing schools to allow them to study alongside able-bodied children to reports of local councils removing coconut trees because of the risk that coconuts might fall and injure pedestrians. ${ }^{71}$ The second is the insurance industry. The Insurance Council of Australia, as the peak organisation representing the insurance industry, has pointed to statistical evidence that Australia was, at one point, the second most litigious country in the world after the United States. ${ }^{72}$ In its submission to a governmental inquiry on personal injury law and public liability insurance in 2002, it argued that the Australian legal system was reaching crisis point because too many Australians wanted 'compensation for any loss, which used to be considered fate, luck or an accident'. ${ }^{73}$

\footnotetext{
${ }^{67}$ Refshauge, above n 4, 4.

${ }^{68}$ Ibid.

${ }^{69}$ Ibid.

${ }^{70}$ Conde, above n 8, 30 .

${ }^{71}$ Ibid 2.

${ }^{72}$ Insurance Council of Australia, Submission to National Ministerial Forum, Public Liability Insurance, March 2002, 11. This argument is strongly criticised by both Davis, 'The Tort Law Crisis', above n 8, and Refshauge, above n 4, 3.

${ }^{73}$ Insurance Council of Australia, above n 72, 11.
} 
The third institution warning about the dangers of litigiousness is the judiciary. Several judges, in their judgments or in extra-curial speeches or articles, criticise over-litigiousness in Australia and the burden this is placing on the courts. Former Chief Justice of the Australian High Court, Sir Gerard Brennan, considered in 1997 that the Australian civil justice system was 'in crisis'. ${ }^{74}$ Gleeson CJ in 2005 warned that Australia was becoming 'a rightsconscious and litigious society, in which people are apt to demand reasons for any decision by which their rights are affected'. ${ }^{75}$ David Ipp, former justice in the New South Wales Court of Appeal, argued in 1994 that clogged courts were leading to 'dissatisfaction with the court system' and 'erosion of confidence in the justice system'. ${ }^{76}$ Queensland judges have been especially scathing in their criticism. In Lade \& Co Pty Ltd v Black, Keane JA remarked:

In a litigious society, enthusiasm for litigation may, in some cases, overwhelm rational consideration of whether 'the game is worth the candle' with the unfortunate result that the costs expended by the parties upon the litigation vastly exceed the monetary value of the matters in dispute. ${ }^{77}$

In Melchior v Cattanach, McMurdo P noted:

[I]n Australian society, we have become accustomed to claimants pursuing claims against insured friends and relatives; we are no longer shocked when a husband sues his wife in a motor vehicle accident case for damages for personal injuries, children sue parents for whom they work when injured in the work place or students sue their school for damages arising from negligence. $^{78}$

In Leslie v Price, Thomas JA raised strongly worded concerns about the ease with which injured Australians could sue for compensation:

[Australian law] ... increasingly permit[s] unrealistic results in [personal injury] cases, in both liability and quantum. Today it is commonplace that claimants with relatively minor disabilities are awarded lump sums greater than the claimant (or defendant) could save in a lifetime. The generous application of these rules is producing a litigious society and has already spawned an aggressive legal industry. I am concerned that the common law is being developed to a stage that already inflicts too great a cost upon the community both economic and social.

\footnotetext{
${ }^{74}$ Gerard Brennan, 'Key Issues in Judicial Administration' (1997) 6 Journal of Judicial Administration 138, 139.

${ }^{75}$ Swain v Waverley Municipal Council (2005) 213 ALR 249, 251.

${ }^{76}$ Ipp, 'Reforms to the Adversarial Process in Civil Litigation — Part I', above n 7, 705.

77 [2006] 2 Qd R 531, 543.

${ }^{78}$ [2001] QCA 246, [60].
} 
In a compensation-conscious community citizens look for others to blame. The incentive to recover from injury is reduced. Self-reliance becomes a scarce commodity. These are destructive social forces. Also much community energy is wasted in divisive and non-productive work. A further consequence is the raising of costs of compulsory third party, employers' liability, public risk and professional indemnity insurance premiums. These costs are foisted upon sectors of the public and in the end upon the public at large. I would prefer that these problems be rectified by the development of a more affordable common law system, but in recent times its development has been all in one direction — more liability and more damages.

I express these concerns in this particular case because authority constrains me to participate in pushing the boundaries further when I think that the time has already been reached when courts should be seriously reconsidering the formulation of firmer control devices than those that currently exist. I fear that we are developing a creature we can no longer control. $^{79}$

\section{CriticismS}

The case put by the media, the insurance industry and the judiciary is a powerful one. But how convincing is it? For example, the media attracts its audience through attention-grabbing stories. Would it not be natural for it to highlight high-stakes and unusual cases rather than describe the 'routine, ${ }^{80}$ contract, torts and property claims that are the bread-and-butter of the court system? Further, as Davis asks, is it not in the interests of the insurance industry to undermine plaintiff rights because they place pressure on insurance affordability and therefore dampen consumer demand for insurance products? ${ }^{81}$ And, finally, Australian judges decide law suits every day in their professional lives. When they make claims about litigious behaviour, are they not relying on an unrepresentative - and therefore unreliable - sample of the Australian population?

The question of Australian litigiousness was independently tested by the ALRC. In its 2000 report on the civil justice system, it conducted the first nation-wide empirical investigation into litigation rates in Australia ${ }^{82}$ and found no 'explosion' in litigation rates. ${ }^{83}$ Although case-loads were increasing in some jurisdictions and civil cases were generally becoming more complex

\footnotetext{
${ }^{79}$ [2002] 2 Qd R 168, 174.

${ }^{80}$ Ramseyer and Rasmusen, above n 40, 5 .

${ }^{81}$ Davis, 'The Tort Law Crisis', above $\mathrm{n} 8$.

${ }^{82}$ ALRC, above $\mathrm{n} 10$.

${ }^{83}$ Weisbrot, above n 10, 242.
} 
and taking longer to resolve, this lent insufficient weight to the view pushed by the media, the legal profession and the judiciary that the legal system was on the verge of crisis. Indeed, according to later studies examining civil filings, litigation has, in general, been declining since the late 1990s. ${ }^{84}$ More recent statistics confirm that litigation continues to decline in the first decade of the 2000s:

\begin{tabular}{|l|l|l|l|l|l|l|l|l|l|}
\hline & NSW & Vic & Qld & WA & SA & Tas & ACT & NT & Total \\
\hline $\begin{array}{l}2009- \\
2010\end{array}$ & 2931 & 3360 & 1833 & 2680 & 1879 & 2164 & 1227 & 3217 & 2687 \\
\hline $\begin{array}{l}2008- \\
2009\end{array}$ & 3119 & 3591 & 2279 & 2781 & 2032 & 2327 & 1671 & 2964 & 2926 \\
\hline $\begin{array}{l}2007- \\
2008\end{array}$ & 3121 & 3703 & 2223 & 2533 & 2063 & 2212 & 1917 & 2808 & 2925 \\
\hline $\begin{array}{l}2006- \\
2007\end{array}$ & 3216 & 3811 & 2306 & 2546 & 2256 & 2418 & 1791 & 3077 & 3024 \\
\hline $\begin{array}{l}2005- \\
2006\end{array}$ & 2295 & 3890 & 2509 & 2678 & 2430 & 2543 & 2407 & 3136 & 3190 \\
\hline
\end{tabular}

Table 1: Lodgements, civil, per 100000 people (all civil courts excluding the family courts, the Federal Magistrates Court and the coroners' courts) ${ }^{85}$

Further, according to a 2011 comparative study drawing on 2007 court data, Ramseyer and Rasmusen found that Australians file nearly four times fewer civil law suits (1542 per 100000 people) than Americans (5806 per 100000 people) and, in an interesting twist, even fewer than the Japanese (1768 per 100000 people). ${ }^{86}$ This study is open to question, however, because the authors' estimation of Australian court filings (1542 per 100000 people is almost half that of official Australian government estimations (3024 per 100000 people: see Table 1 above). Yet, even if adjusted, Australian litigation levels are still significantly lower than those in the United States; indeed, they are closer to Japanese than American rates.

\section{Conclusion}

So how litigious are Australians? Do Australians seek informal resolution of their conflicts, in order to preserve their social relationships, or are they quick to assert their rights? Which prevailing view of Australian identity best

\footnotetext{
${ }^{84}$ Davis, 'The Tort Law Crisis', above n 8, 866-7; Refshauge, above n 4, 1-2.

${ }^{85}$ Productivity Commission, above n 16, Table 7A.4.

${ }^{86}$ Ramseyer and Rasmusen, above n 40, 4.
} 
explains Australians' attitude to law? Put differently, if something goes wrong, do you expect a 'she'll be right, mate' or a 'she has rights, mate'?

Access to lawyers is not an issue. Indeed, according to Ramseyer and Rasmusen, Australia has nearly the same number of lawyers per capita as the United States. ${ }^{87}$ But the data on civil court lodgements clearly show that Australians do not necessarily retain them at the same rate as Americans or, if they do, not primarily for the purposes of contesting their disputes in the courts. Nevertheless, there are enough lodgements to show that Australians are not unwilling to make use of the courts.

All this points to the conclusion that culture - or, at least, cultural stereotyping - is an unreliable guide to Australian litigating behaviour. Such is the key lesson derived from the comparative law work analysing American and Japanese attitudes to law. As the Australian quantitative research reveals, Australians are neither embracing a new American-style culture of litigiousness nor unduly resisting resort to formal law as somehow antithetical to inherently Australian values of fair play and common sense. The truth lies somewhere in between.

This opens up rich prospects for further inquiry. If Australian litigiousness lies somewhere between the American and Japanese extremes, does this suggest that it is a model for other nations to emulate? More importantly, what explains the current state of affairs? As this article has pointed out, the Australian literature has been effective in debunking the myth of a civil justice system in crisis; but it has largely failed to give the reasons why Australians are using the courts and formal law at current levels. Perhaps the brief burst of scholarly interest in Australian litigiousness, inspired by the release of the 2000 ALRC report on Australian civil justice, has largely dissipated because it was too narrowly focused on the question — now largely rejected — of overlitigiousness in Australia. This is to be contrasted with the research activity on American and Japanese litigation which is not only continuing unabated, but is also offering up new explanatory paradigms for continuing or emerging trends in each country's litigation profiles. ${ }^{88}$

This suggests an additional lesson that comparative law may have for future research into Australian litigiousness. After decades of research, comparative

\footnotetext{
${ }^{87}$ Ibid 27.

${ }^{88}$ See, eg, Tom Ginsburg and Glenn Hoetker, 'Effects of Liberalization on Litigation: Notes Toward a Theory in the Context of Japan' (2009) 8 Washington University Global Studies Law Review 303 (arguing that market liberalisation is contributing to an upward trend in litigation rates in Japan); Ramseyer and Rasmusen, above n 40 (arguing that dysfunctional doctrinal approaches to class actions and product liability disputes explain why American litigation rates exceed those in comparable democracies).
} 
law has revealed a wealth of explanatory models which can be tested in the Australian context. The literature on Japanese litigiousness alone offers some intriguing theoretical paradigms - cultural, institutional, political and economic — that might bear fruit in future empirical studies on Australian legal consciousness.

Law, in short, matters in Australia - but, according to the consensus in the literature, not too much. But how does law matter in Australia? To paraphrase again from Hamlet, that is the next question. And comparative law is the torch that can guide the next generation of scholars into this new scholarly terrain. 
